\section{Development of Black Spruce Layers in Quebec and Ontario}

\author{
By W. Stanek ${ }^{1}$
}

\author{
'Research Officer, Canada Dept. of \\ Forestry and Rural Development, \\ Forest Research Laboratory, \\ P.O. Box 35 , Sillery, \\ Quebec 6, P.Q. \\ Oxf. 232.328.4:174.7.
}

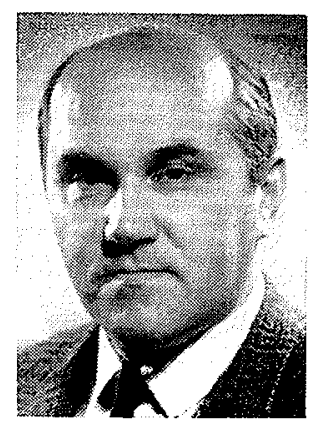

\begin{abstract}
Black spruces of layer or seed origin develop into merchantable trees with similar growth in height, diameter and volume. Layerings tend to have a poorer stem form than seedlings, especially under adverse growing conditions. However, stem form of old layering trees is considerably better. The proportion of layerings and seedlings is influenced by stand history. Black spruce stands undisturbed for a long time consist largely of layerings. After fire, scarification, or exposure of mineral soil, stands regenerate mainly from seedlings. Stocking of black spruce is satisfactory where advance growth has been preserved after cutting, whether it is of layer or of seed origin.
\end{abstract}

\section{Resume}

Les marcottes et les semis d'épinette noire produisent des arbres de valeur marchande dont la croissance, le diamètre et le volume sont les mêmes. Les marcottes ont tendance à avoir une tige moins droite que les semis, particulièrement lorsque les conditions de croissance sont pauvres; mais la forme des vieilles marcottes est considérablement meilleure. La proportion des marcottes par rapport aux semis est influencée par l'histoire du peuplement. Les peuplements intacts pendant une longue période consistent en grande partie de marcottes. Après un incendie, un scarifiage ou l'exposition du sol minéral, les peuplements se régénèrent surtout par semis. Après coupe, des peuplements d'épinette noire d'une bonne densité ont été obtenus aux endroits oì les semis préexistants avaient été protégés, qu'ils fussent des marcottes ou non.

\section{Introduction}

Vegetative propagation by layering" is characteristic of black spruce (Picea mariana (Mill.) B.S.P.). The phenomenon and the process were reported and described by Cooper (1911), Kenety (1917), Gates (1938), Bannan (1942), and others. Layering takes place when a living branch becomes imbedded in a moist medium and produces roots. The branch connection may persist for a long time and, when it can be traced from the layer to the parent tree, provides proof of origin. Trees of layer ${ }^{3}$ origin can also be detected by microscopic examination of the layer "root", which retains the primary xylem and phloem structure of a branch (Stanek, 1961). Vincent (1964) reported that layers developed as well as, or better than, seedlings when exposed to similar conditions and that trees of the same initial size did not differ much in response to release regardless of origin. Kenety (1917), Bellefeuille (1935), LeBarron (1948), Hosie (1954), Shoenicke and Schneider (1954), and Stanek (1961) found that trees of merchantable size could develop from layers of black spruce.

This investigation assessed the importance of layering for reproduction of black spruce stands. The growth performance of trees of layer and of seed origin, their respective roles in the restocking of logged areas, and their contribution to volume production of black spruce stands were investig-

\footnotetext{
"Layering here means a tree of layer origin that grows independently of the parent tree. It also designates the process of loyer formation.

${ }^{3}$ A layer, according to Empire Forestry Association (1953), is an attached branch that has rooted and is capable of independent growth.
} 
ated. Data were collected in the vicinities of Chibougamau, Quebec, and Cochrane, Ontario, primarily in the autumn of 1966.

\section{Methods}

The stands studied were classified by forest association after Hatcher and Jurdant (1965) in the Chibougamau Forest Reserve, a region of coarse, fluvio-glacial soil parent material, and after Stanek (1961) in the Cochrane area of the "Clay Belt". The distribution of the twenty-three 1/40-acre square plots by area and association is given in Table 1 .

Table 1

Distribution of 23 Plots in Mature or Young Black Spruce Stands According to Forest Associations

\begin{tabular}{ccc} 
Forest association & Mature & Young \\
\cline { 2 - 3 } & $\begin{array}{c}\text { Stand } \\
\text { number }\left({ }^{1}\right)\end{array}$ & $\begin{array}{c}\text { Stand } \\
\text { number }\end{array}$ \\
\end{tabular}

Kalmieto-Piceetum Cla-

donietosum cum (dry)

Kalmieto-Piceetum Typicum (wet)

Kalmieto-Piceetum Sphagnetosum

Sphagno-Piceetum Chamaedaphnetosum

Sphagno-Piceetum Alnetosum

Abieti-Piceetum

Hypno-Piceetum

Peat Muskeg

Spruce Fir Flat

4

1 and 2

8 and $9 \quad 12,15$ and 16

Spruce Fir Slope
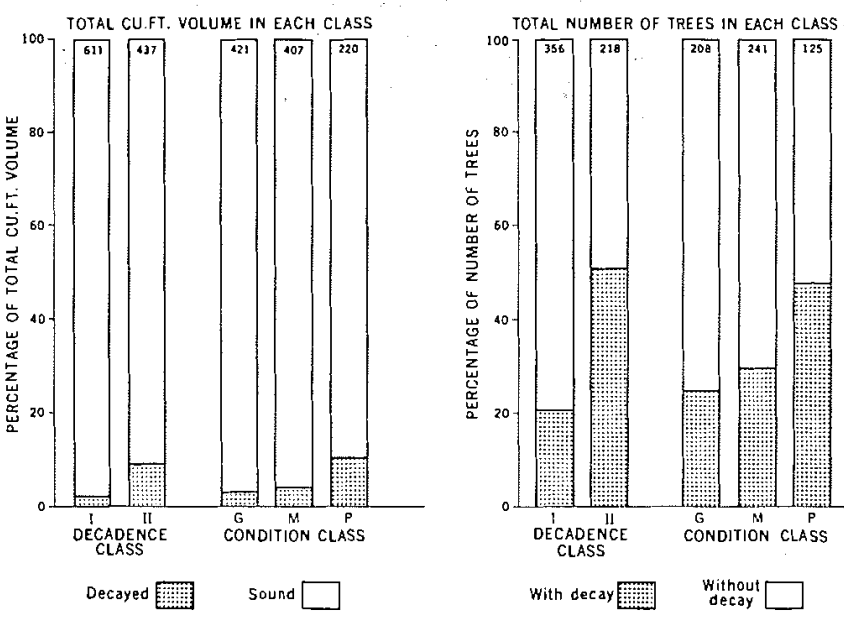

Figure 1. Three arbitrarily defined stem-form closses for block spruce: good (1); medium (2); poor (3).

values. Stand volumes for trees larger than $3.5 \mathrm{in}$. $\mathrm{dbh}$ were calculated by determining the diameter of the trees of average $D^{2}\left(\mathrm{dbh}^{2}\right)$ (Smith and Breadon, 1964), estimating the volume of each, and multiplying by the average number of trees per acre.

\section{Results}

The stem analyses showed that trees of layer origin could grow as well as, or better than, trees of seed origin. Height-on-age curves (Fig. 2), constructed from 10 stem analyses of layer origin and three of seed origin, indicate that, in a given association, trees of both origins grew similarly in height.

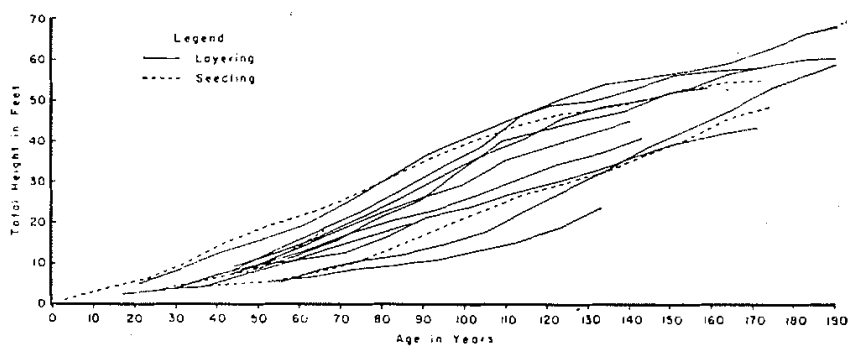

Figure 2. Height-on-age curves of black spruce trees of layer and of seed origin from the Kalmieto-Piceetum Typicum Association.

In general, trees of layer and seed origin have been shown to be similar in growth (Cooper, 1911), (Kenety, 1917), (Stanek, 1961), (Vincent, 1964). The impression that trees of layer origin do not develop into trees of merchantable size probably arose because many of the slowly growing specimens were still connected to the parent tree and were easily recognized, while fast-growing, wellformed trees were automatically classified as originating from seed. Well-formed young layerings in moss (Fig. 3), layerings of sapling and pole size (Fig. 4) and layerings of tree size (Fig. 5) can easily be mistaken for seed-origin stems.

Layerings have somewhat poorer form than trees of seed origin (Table 2). An analysis of variance showed that variation in form class (Fig. 1) was primarily a function of origin (layering or seedling) and of age ( 1 per cent significance). Larger trees, 


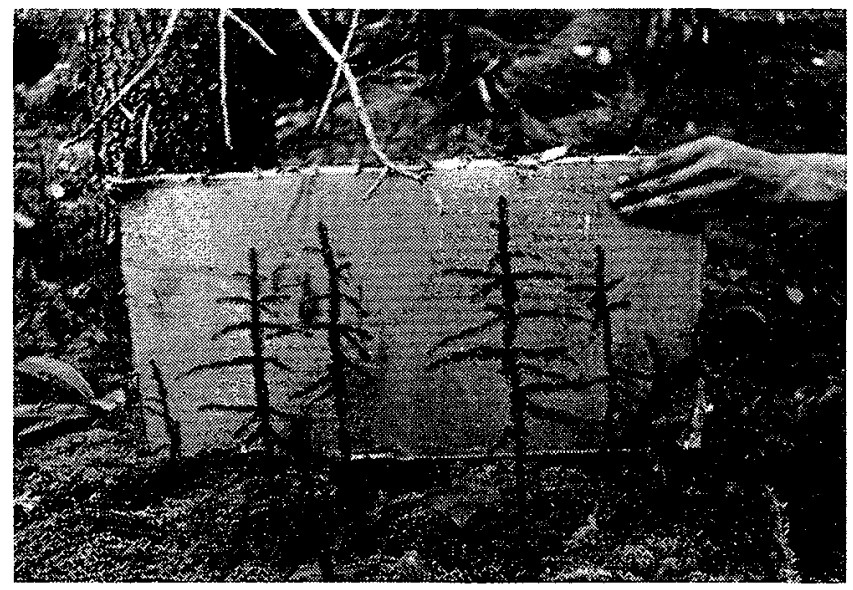

Figure 3. Small Black spruce trees of layer origin in sphagnum moss.

particularly those of layer origin, were of significantly better form than smaller trees ( 1 per cent significance). Casual observations also indicated that the straightness of stems was a function of the condition of the stand. For example, in uneven-aged stands of the Kalmieto Piceetum Typicum Sphagnetosum Association approximately 16, 48, and 36 per cent of the layerings were of form class 1,2 and 3 respectively. In the second-growth stands of the same association, without competition from above, 60,26 and 12 per cent of the layerings were of form class 1,2 , and 3 respectively.

A great part of the volume of our mature black spruce forests consists of layerings, but the proportion present depends greatly upon stand history (Table 3 ). Stands originating with fire appear to regenerate largely by seed. In stands with no recent

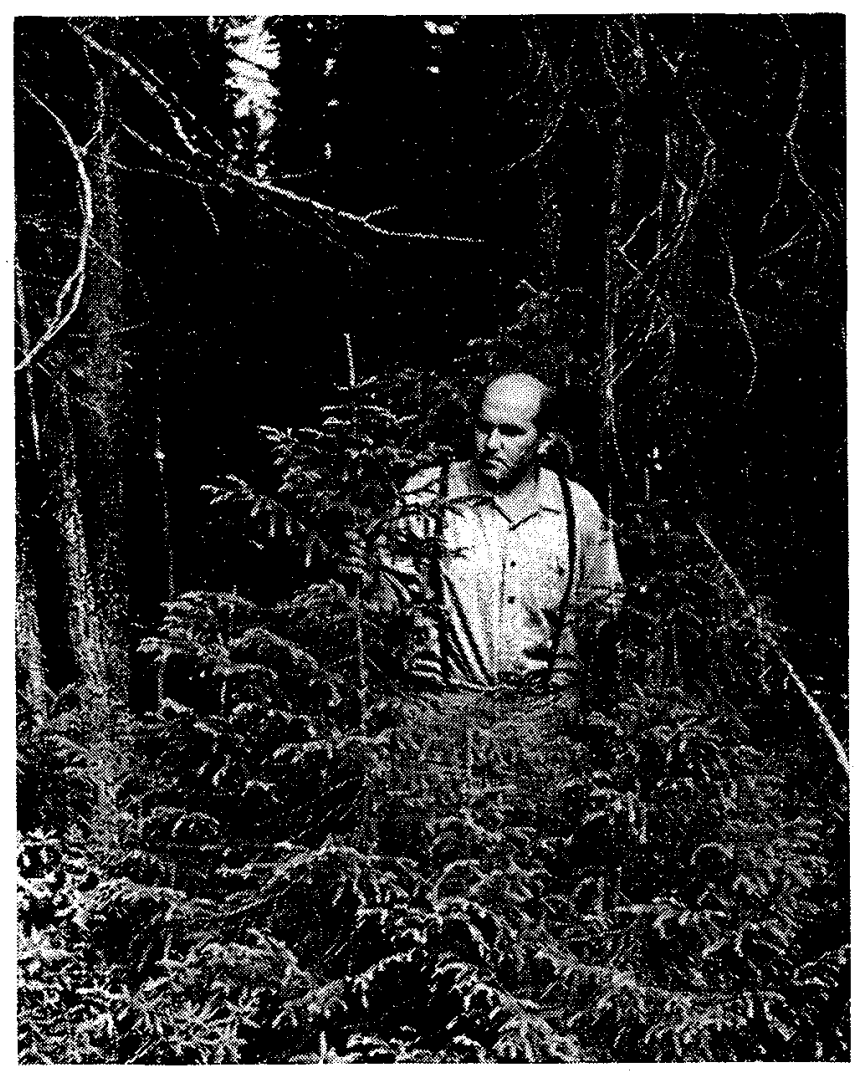

Figure 4. Black spruce saplings of layer origin.

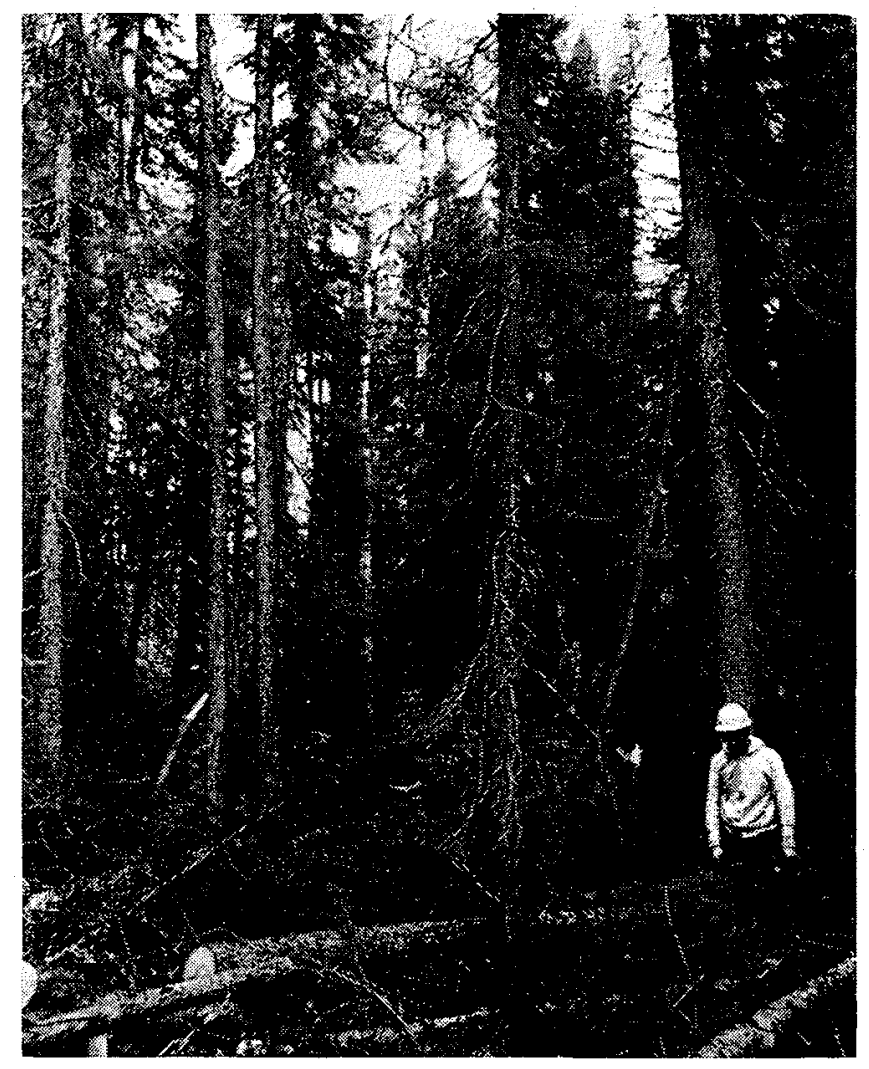

Figure 5. Trees of layer origin in the Kalmieto-Piceetum Typicum Sphagnetosum Association.

fire history or with substantial depositions of organic material, volume was made up mainly of layerings. This suggests that the proportion by volume of trees of layer origin varies directly with the length of time black spruce stands remain undisturbed and with the quantity of organic material accumulated.

\section{Discussion}

In black spruce stands of northern Quebec and Ontario, reproduction through layering is common and on many sites provides the major source of reproduction. The growth rate of layerings compares favourably with that of seedlings. The stem form of most layerings in favourable environments is good. Many black spruce stands have originated from advance growth through layers, and it is therefore increasingly important to consider the effect of mechanical logging techniques on reproduction. It seems possible that, by destroying advance growth, mechanized operations could render black spruce stands unproductive for extended periods (Vincent, 1965). Layerings are as important as seedlings in establishment of black spruce stands after cutting, and their importance is enhanced because layering is frequently the only way whereby cutover land is restocked naturally.

This suggests to the forest manager that preservation and protection of advance growth in black spruce stands will serve a multiple purpose. It will save expense in artificially regenerating large areas, shorten the rotation period considerably, and sustain yield by eliminating unproductive periods. Where advance growth is destroyed, it will probably be necessary to regenerate artificially. 
Table 2

Relationship between Stem Form and Size Classes in Trees of Seedling and of Layer Origin

\begin{tabular}{|c|c|c|c|c|c|c|c|c|}
\hline \multirow[b]{3}{*}{$\begin{array}{l}\text { Size class } \\
\text { (height in } \mathrm{ft} ., \mathrm{dbh} \text { in in.) }\end{array}$} & \multicolumn{4}{|c|}{ Layer-origin trees } & \multicolumn{4}{|c|}{ Seed-origin trees } \\
\hline & \multicolumn{3}{|c|}{ Stem-form classes } & \multirow[b]{2}{*}{$\begin{array}{l}\text { Total } \\
\text { number }\end{array}$} & \multicolumn{3}{|c|}{ Stem-form classes } & \multirow[b]{2}{*}{$\begin{array}{l}\text { Total } \\
\text { number }\end{array}$} \\
\hline & $\stackrel{1}{\%(1) \%}$ & ${ }^{2}(1)$ & $\begin{array}{c}3 \\
\%(1)\end{array}$ & & $\stackrel{1}{\not{ }^{1}}$ & $\stackrel{2}{\%(1)}$ & $\begin{array}{l}3 \\
\%\left({ }^{1}\right)\end{array}$ & \\
\hline $0.1 \mathrm{ft} .-2.0 \mathrm{ft}$. & 11 & 58 & 31 & 834 & 62 & 32 & 6 & 47 \\
\hline $2.1 \mathrm{ft} .-0.6 \mathrm{in}$. & 24 & 55 & 21 & 418 & 54 & 28 & 18 & 65 \\
\hline 0.7 in. 3.5 in. & 16 & 51 & 33 & 151 & 61 & 33 & 6 & 33 \\
\hline More than 3.5 in. & 36 & 57 & 7 & 44 & 62 & 34 & 4 & 52 \\
\hline All size classes & 16 & 56 & 28 & 1447 & 59 & 31 & 10 & 197 \\
\hline
\end{tabular}

${ }^{1}$ ) Percentage of total number of trees (Total number) per category.

Table 3

Volume of Layerings (L) in Percent of Total Black Spruce (Sb) Volume in Several Forest Stands

\begin{tabular}{|c|c|c|c|c|c|}
\hline \multirow[b]{2}{*}{ Plot } & \multirow[b]{2}{*}{ Forest stand description and history } & \multirow[b]{2}{*}{$\begin{array}{l}\text { Dominant height } \\
\text { at } 100 \text { years, } \mathrm{ft} .\end{array}$} & \multirow[b]{2}{*}{$\begin{array}{l}\text { Average } \\
\text { dbh, in. }\end{array}$} & \multicolumn{2}{|c|}{ Total volume per acre of } \\
\hline & & & & $\begin{array}{l}\text { all } \mathrm{Sb}, \mathrm{dbh} 3.5 \mathrm{in} . \\
\text { and more, cu. ft. }\end{array}$ & $\begin{array}{l}\mathrm{L} \text { only, percent } \\
\text { of total }\end{array}$ \\
\hline \multirow[b]{2}{*}{1} & Stands with fire history & & & & \\
\hline & $\begin{array}{l}\text { Mature } \mathrm{Sb} \text {, well stocked, after } \\
\text { burn of } 1826\end{array}$ & 45 & 75 & 4420 & 0 \\
\hline 8 & Mature $\mathrm{Sb}$, open, after burn of & & & I-10 & \\
\hline & 1779 & 35 & 6.0 & 2928 & 10 \\
\hline 9 & Mature Sb, well stocked, on gentle & & & & \\
\hline & $\begin{array}{l}\text { lower slopes, after fire of } 250 \\
\text { years ago }\end{array}$ & 35 & 7.3 & 5460 & 94 \\
\hline 10 & Mature, mixed, uneven-aged, on & & & & \\
\hline \multirow{4}{*}{11} & $\begin{array}{l}\text { well-drained river bank, after } \\
\text { fire of } 1826\end{array}$ & 48 & 7.2 & 3648 & 0 \\
\hline & Old, uneven-aged, mixed on mo- & & & & \\
\hline & $\begin{array}{l}\text { derately well-drained site, after } \\
\text { fire of } 1826\end{array}$ & 60 & 5.7 & 1148 & 7 \\
\hline & Stands without fire history & & & & \\
\hline \multirow{3}{*}{$\begin{array}{l}\text { OL } 4 \\
\text { OL } 10\end{array}$} & $\begin{array}{l}\text { Mature Sb, well stocked, on or- } \\
\text { ganic soil }\end{array}$ & 40 & 6.9 & 3817 & 100 \\
\hline & Old, uneven-aged $\mathrm{Sb}$, well stocked, & & & & \\
\hline & undisturbed by fire & 53 & 6.9 & 3665 & 95 \\
\hline
\end{tabular}

\section{References}

BANNAN, M. W. 1942. Notes on the origin of the adventitious roots in the native Ontario conifers. Amer. Jour. Bot. 29: 593-598.

BELLEFEUILLE, R. 1935. La reproduction des peuplements d'Epinette noire dans les forets du NordQuebec. For. Chron. 11 (4): 323-340.

COOPER, W. S. 1911. Reproduction by layering among conifers. Bot. Gaz. 52: 369-379.

EMPIRE FORESTRY ASSOCIATION. 1953. British Commonwealth forest terminology. E.F.A. London, 163 pp.

GATES, F. C. 1938. Layering in black spruce. Amer. Midland Naturalist 19: 589-594.

HATCHER, R. J. and M. L. G. JURDANT. 1965. Chibougamau Research Forest Quebec. Can. Dept. For., Res. Br., Proj. Rep. 65-Q-5, 16 pp.

HOSIE, R. C. 1954. The regeneration of cutover areas. For. Chron. 30 (2): 128-130.

KENETY, W. H. 1917. Regeneration of black spruce. Jour. For. 15: 446-448.
LeBARRON, R. K. 1948. Silvicultural management of black spruce in Minnesota. U.S.D.A., For Serv., Lake States For. Exp. Sta., Circular No. 791.

SCHOENICKE, R. E. and A. E. SCHNEIDER. 1954. The extent and character of regeneration in uncut black spruce (Picea mariana) swamp stands of north central Minnesota. Univ. Minn. School For., For. Note 26, $2 \mathrm{pp}$.

SMITH, J. H. G. and R. E. BREADON. 1964. Combined variable equations and volume basal area ratios for total cubic foot volumes of the commercial trees of B.C. For. Chron. 40 (2) : 258-261.

STANEK, W. 1961. Natural layering of black spruce in northern Ontario. For. Chron. 37 (3): 245-258.

VINCENT, A. B. 1964. Comparative growth of black spruce seedlings and layers under an alder canopy. Reprint. in Pulp and Paper Mag. of Can., Woodlands Review Section. Can. Dept. For., For. Res. Br. Contrib. No. 630, 3 pp.

VINCENT, A. B. 1965. Black spruce, a review of its silvics, ecology and silviculture. Can. Dept. For., Publ. No. 1100, 79 pp. 